Article

\title{
Bacterial and Fungal Community Dynamics and Shaping Factors During Agricultural Waste Composting with Zeolite and Biochar Addition
}

\author{
Xin Wu, Liheng Ren, Lin Luo *, Jiachao Zhang *, Lihua Zhang and Hongli Huang \\ College of Resources and Environment, Hunan Agricultural University, Changsha 410128, Hunan, China; \\ starrywuxin@163.com (X.W.); rliheng@163.com (L.R.); zhanglihua029@163.com (L.Z.); \\ huanghongli@hunau.edu.cn (H.H.) \\ * Correspondence: linluo.huau@foxmail.com (L.L.); jiachao.zhang@hunau.edu.cn (J.Z.); \\ Tel.: +86-0731-84618166 (J.Z.)
}

Received: 9 August 2020; Accepted: 27 August 2020; Published: 30 August 2020

\begin{abstract}
Bacterial and fungal communities play significant roles in waste biodegradation and nutrient reservation during composting. Biochar and zeolite were widely reported to directly or indirectly promote microbial growth. Therefore, the effects of zeolite and biochar on the abundance and structure of bacterial and fungal communities and their shaping factors during the composting of agricultural waste were studied. Four treatments were carried out as follows: Run A as the control without any addition, Run B with zeolite (5\%), Run C with biochar (5\%), and Run D with zeolite $(5 \%)$ and biochar $(5 \%)$, respectively. The bacterial and fungal community structures were detected by high-throughput sequencing. Redundancy analysis was used for determining the relationship between community structure and physico-chemical parameters. The results indicated that the addition of biochar and zeolite changed the physico-chemical parameters (e.g., pile temperature, $\mathrm{pH}$, total organic matter, ammonium, nitrate, and water-soluble carbon) during the composting process. Zeolite and biochar significantly changed the structure and diversity of bacterial and fungal populations. Moreover, the bacterial community rather than the fungal community was sensitive to the biochar and zeolite addition during the composting process. Community phylogenetic characteristics showed that Nocardiopsaceae, Bacillaceae, Leuconostocaceae, Phyllobacteriaceae, and Xanthomonadaceae were the predominant bacterial species at the family-level. Chaetomiaceae and Trichocomaceae were the two most dominant fungal species. The $\mathrm{pH}$, total organic matter, and nitrate were the most important factors affecting the bacterial and fungal population changes during the composting process.
\end{abstract}

Keywords: composting; zeolite; biochar; microbial community structure; shaping factor

\section{Introduction}

Composting has been widely considered to be an efficient way to convert organic wastes into valuable products [1-3]. A large amount of carbon and nitrogen (9.6-50\%), mainly in the form of ammonia $\left(\mathrm{NH}_{3}\right)$, methane $\left(\mathrm{CH}_{4}\right)$, and nitrous oxide $\left(\mathrm{N}_{2} \mathrm{O}\right)$, are lost from the raw materials during composting [4,5]. According to the International Panel on Climate Change (IPCC), $\mathrm{CH}_{4}$ and $\mathrm{N}_{2} \mathrm{O}$ contribute 30 and 210 times more to global warming than carbon dioxide $\left(\mathrm{CO}_{2}\right)$, respectively. The release of these gases will not only reduce compost nutrients but also cause serious air pollution $[4,6,7]$. Therefore, it is necessary to limit gas emissions to provide an environmentally friendly process for organic waste composting.

Studies have been performed on nitrogen conservation characteristics during waste composting [8]. Many physical, chemical, and biological methods have been widely used in the composting process to fix 
the carbon and nitrogen nutrients and improve the final product quality. Additives of alkaline minerals (e.g., coal zeolite, fly ash, bentonite, and red mud) have been proved to be effective in improving compost fertility [9-11]. Among these additives, zeolite is widely used in nitrogen conservation research, as its substance has the crystalline hydrate aluminosilicate and excellent high negative charge sites of alkaline metals. Zeolite can absorb cations including $\mathrm{NH}_{4}{ }^{+}$in environmental media such as water, soils, and composting piles [12]. Moreover, biochar consists of carbonaceous solid by-products that are formed by organic biomass pyrolyzation or gasification under hypoxic conditions. Biochar has many stubborn aromatic ring structures and has been extensively used in heavy metal contaminated soil restoration, carbon sequestration, and $\mathrm{CO}_{2}$ emission reduction [13-17]. The added biochar consequently alleviates the initial low $\mathrm{pH}$ at the thermophilic stage during composting [17].

As the bulking agents for composting, biochar and zeolite reduce the emissions of various gases and act as biofilters because of their porous microstructure [18]. Biochar and zeolite have been extensively reported to be beneficial for organic matter degradation [7], nitrogen transformation [7,19], and gas emission [19-22] during the composting of agricultural waste since they can regulate moisture content and provide optimal free space for microbial growth. It appeared that adding zeolite and biochar influenced the microbial community, composting performance, and the quality of the final product. Despite this, reports on how the addition of biochar and zeolite affect microbial communities and functional genes during composting are still lacking. Moreover, the addition of zeolite and biochar will affect the physico-chemical parameters, while the microbial communities are sensitive to the changes in these parameters. Up to now, little information has been made available on the shaping factors of variations in microbial communities under different amendment strategies of biochar and zeolite. Identifying and tracing the microbial community characteristics during composting will deepen our comprehensive understanding of the microbiological mechanism of nitrogen balances and loss control in composting systems.

Thus, the purpose of this experiment was to investigate the effects of zeolite and biochar on bacterial and fungal communities during the composting of agricultural waste. The structure of bacterial and fungal communities was determined by the high-throughput sequencing technique. The relationship between the structure of the microbial community and physico-chemical parameters was determined by multivariate analysis. It is important to figure out the microbiological mechanism and provide theoretical guidance for the management during composting.

\section{Materials and Methods}

\subsection{Raw Materials and Experiment Set-Up}

Straw and several discarded vegetables were collected from the vegetable market of the Hunan Agricultural University in Changsha, Hunan, China, and then air-dried and cut into 1-3 mm lengths with a sickle. Straw is difficult to decompose, and vegetables are easily degradable materials as organic materials. Fresh paddy red soils were collected in the Hunan Academy of Agricultural Sciences, where plant debris and rocks were removed through a 60-mesh sieve and added to compost piles to provide the essential nutrients and microbial communities. Bran was selected to regulate the $\mathrm{C} / \mathrm{N}$ ratio of the compost medium. The features of these raw initial materials can be seen in Table 1 .

Table 1. The physico-chemical properties of raw materials.

\begin{tabular}{cccccccc}
\hline Raw Materials & TOC (\%) & TN (\%) & C/N Ratio & Moisture (\%) & pH & $\begin{array}{c}\text { Ammonium } \\
(\mathbf{m g} / \mathbf{k g})\end{array}$ & $\begin{array}{c}\text { Nitrate } \\
(\mathbf{m g} / \mathbf{k g})\end{array}$ \\
\hline Rice straw & 452.6 & 8.5 & 53.2 & 5.2 & - & - & - \\
Vegetable & 89.5 & 3.9 & 22.9 & 84.4 & 7.4 & 16.9 & 11.2 \\
Soil & 67.1 & 2.5 & 26.8 & 17.6 & 6.2 & 47.3 & 52.1 \\
Bran & 474.8 & 44.5 & 10.7 & 12.5 & - & - & - \\
\hline
\end{tabular}

- Data was not determined; TOC: Total organic carbon; TN: Total nitrogen. 
Straw, soil, bran, and vegetables were mixed evenly in a ratio of 11:8:2:3 (fresh weight) [2,23]. Four different treatments were conducted as follows: Run A was the control treatment without any addition and Runs B, C, and D were added with zeolite (5\%), biochar (5\%), and zeolite $(5 \%)+$ biochar (5\%), respectively. The initial $\mathrm{C} / \mathrm{N}$ ratio was approximately $25: 1$, and organic matter content was $60-65 \%$, respectively. Clinoptilolite zeolite used in this study can absorb and retain nutrients on its microcellular structures. Biochar was obtained from the Zhejiang Biochar Engineering Technology Research Center (ZJBETRC) by rice straw pyrolysis at $500{ }^{\circ} \mathrm{C}$ for $3 \mathrm{~h}$. The total organic matter (TOC) and $\mathrm{pH}$ for zeolite and biochar were $12.25 \mathrm{mg} / \mathrm{kg}$ and 7.6 and $50.0 \mathrm{mg} / \mathrm{kg}$ and 9.08 , respectively. To avoid a possible anaerobic condition, the piles were turned once every day in the first 2 weeks and three times every week afterward.

\subsection{Parameters Determination}

Sub-samples were collected from different positions in the middle of piles on days $0,1,2,3,5$, $7,12,18,26,38$, and 50, respectively. Samples for molecular analysis were mixed before use and stored at $-20{ }^{\circ} \mathrm{C}$, and those for the physico-chemical parameter determination were stored at $4{ }^{\circ} \mathrm{C}$. Pile temperature, $\mathrm{pH}$, total organic matter (TOM), water-soluble carbon (WSOC), moisture, ammonium $\left(\mathrm{NH}_{4}{ }^{+}-\mathrm{N}\right)$, and nitrate $\left(\mathrm{NO}_{3}{ }^{-}-\mathrm{N}\right)$ were detected following the methods mentioned previously $[2,23]$. The TOC content of samples was obtained by TOM/1.724. After sampling, the moisture content of each pile was adjusted around $50-60 \%$ by adding sterile water.

\subsection{DNA Extraction and High-Throughput Sequencing}

Compost samples were freeze-dried before genomic DNA extraction. Approximately $0.5 \mathrm{~g}$ of the samples were used for DNA extraction by using the PowerSoil kit (Bioteke, Beijing, China). DNA extracts for all samples were mixed to reduce variation and stored at $-20^{\circ} \mathrm{C}$. Amplification of the $16 \mathrm{~S}$ rRNA and 18S rDNA genes used primers 338F/805R and ITS1F/ITS2R [24,25], respectively. PCR reaction was carried out in a $50 \mu \mathrm{L}$ mixture consisting of $25 \mu \mathrm{L}$ of $2 \times$ Premix Taq (Takara Biotechnology, Dalian Co. Ltd., Dalian, China), $2 \mu \mathrm{L}$ of each primer, $1 \mu \mathrm{L}$ of DNA extract, and $20 \mu \mathrm{L}$ of nuclease-free water. Thermal cycle protocol was as follows: $95^{\circ} \mathrm{C}$ for $3 \mathrm{~min}$, followed by 27 cycles of $95^{\circ} \mathrm{C}$ for $30 \mathrm{~s}$, $55^{\circ} \mathrm{C}$ for $30 \mathrm{~s}$, and $72{ }^{\circ} \mathrm{C}$ for $45 \mathrm{~s}$; and $72{ }^{\circ} \mathrm{C}$ for $10 \mathrm{~min}$.

The PCR amplification products were sequenced by Magigene Biotechnology Co. Ltd. (Shanghai, China) of Illumina Hiseq 2500 sequencing platform. Low-quality reads were filtered by using Trimmomatic software (v.0.33). FLASH was used to merge the filtered reads into single and longer sequences (v.1.2.11). Sequences with an average mass value of $>40$ and greater than $100 \mathrm{bp}$ were divided into operational taxonomic units (OTUs) with $97 \%$ similarity. The representative sequence for each OTU was classified using the Ribosome Database Project Classifier with the confidence threshold of 0.80 .

\subsection{Data Analysis}

The physico-chemical parameters were determined in triplicate. SPSS (v.11.5) was used for a one-way analysis of variance to determine if there was any significant difference between the parameters for different treatments. Canoco 5.0 could be used for ascertaining the multivariate relationships between physico-chemical parameters and bacterial or fungal structure. The linear or unimodal response model was tested by detrended correspondence analysis (DCA). The length of the first ordination axis for DCA was 0.875 and 2.890 for bacterial and fungal community structure, indicating a clear linear species response [26]. Thus, a redundancy analysis (RDA) was chosen. Forward selection and variance partitioning analysis were subsequently conducted to detect which parameter had a significant impact on the microbial community structure and to distinguish the impact of each significant parameter. The significant factor was only kept in the Monte Carlo permutation models $(n=499)$, and the other significant one(s) was/were used as covariables. $F$ and $p$ values were obtained using Monte Carlo permutations. 


\section{Results}

\subsection{Physico-Chemical Parameters}

The physico-chemical parameters for different treatments are presented in Figure 1. The maximum pile temperatures of Runs A, B, C, and D were 67.0, 64.5, 65.0, and $66.0^{\circ} \mathrm{C}$, respectively. A high temperature $\left(>50^{\circ} \mathrm{C}\right)$ was maintained for more than five days for each treatment (Figure 1a). Compared with Run A, the high-temperature period in biochar/zeolite treatments was shortened as biochar and zeolite addition might accelerate the decomposition of organic materials during the first fermentation phase. The pile temperature in Run B was slightly higher during the thermophilic stage and lower during the cooling and maturity stages. The $\mathrm{pH}$ increased significantly during the first 30 days, with the most increase in biochar treatment during days 3-18 which would be induced by the alkalinity properties of biochar, and decreased slowly afterward in all piles until the end of composting, except for Run D (Figure 1b). Due to the ammonization of the microbial population to the nitrogenous organic matter in the compost matrix, a large amount of ammonia was volatilized, and the $\mathrm{pH}$ rose rapidly during the first fermentation stage. The $\mathrm{pH}$ values at the end of the maturity stage in Runs A-D were $8.62,9.09,8.93$, and 9.57, respectively.

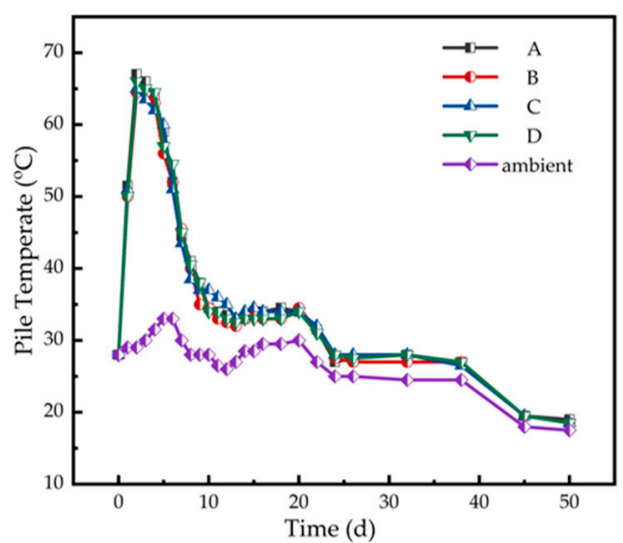

(a)

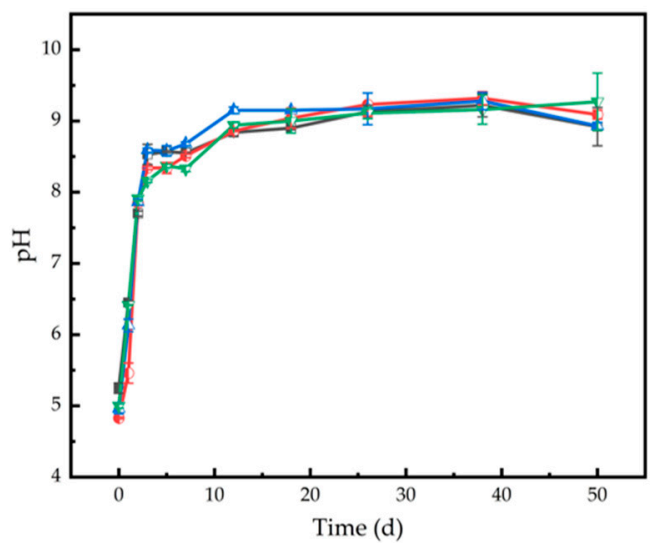

(b)

Figure 1. Changes of (a) pile temperature and (b) $\mathrm{pH}$ for different treatments during agricultural waste composting. Run A: control; Run B: zeolite addition (5\%); Run C: biochar addition (5\%); Run D: zeolite $(5 \%)+$ biochar $(5 \%)$ addition.

Due to the increasing $\mathrm{pH}$ value at the thermophilic stage, the $\mathrm{NH}_{4}{ }^{+}-\mathrm{N}$ rapidly accumulated and peaked on day 3 for Runs A and B, and on day 2 for Runs C and D (Figure 2a). $\mathrm{NH}_{4}{ }^{+}-\mathrm{N}$ fell to a low level due to $\mathrm{NH}_{3}$ volatilization and microbial immobilization. The final $\mathrm{NH}_{4}{ }^{+}-\mathrm{N}$ in all piles were lower than $400 \mathrm{mg} / \mathrm{kg}$ with values in Runs A-D being 256.63, 292.39, 293.93, and 299.48 mg/kg dry weight (DW), respectively. There were significant differences in $\mathrm{NH}_{4}{ }^{+}-\mathrm{N}$ accumulations in $\mathrm{Runs} \mathrm{B}, \mathrm{C}$, and D during the first three days compared with Run $\mathrm{A} . \mathrm{NO}_{3}{ }^{-}-\mathrm{N}$ in Runs A-D were 335.67, 311.80, 324.11 , and $344.63 \mathrm{mg} / \mathrm{kg}$ DW at the beginning of composting, respectively (Figure $2 \mathrm{~b}$ ). As the pile temperature increased rapidly, the activity of nitrifiers might have been inhibited and denitrifiers was stimulated, thus the concentration of $\mathrm{NO}_{3}{ }^{-}-\mathrm{N}$ decreased rapidly in the first few days. The differences among these treatments during the early stage revealed that the biochar and zeolite addition was useful to the nitrification activity in the early stage. The final content of $\mathrm{NO}_{3}{ }^{-}-\mathrm{N}$ was $4.46,4.71,4.47$, and $4.99 \mathrm{mg} / \mathrm{kg}$ DW for Runs A, B, C, and D, respectively (Figure 2b). 


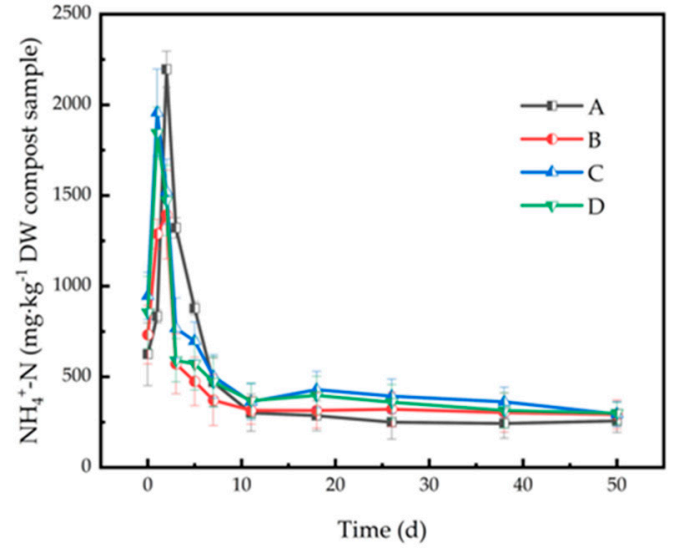

(a)

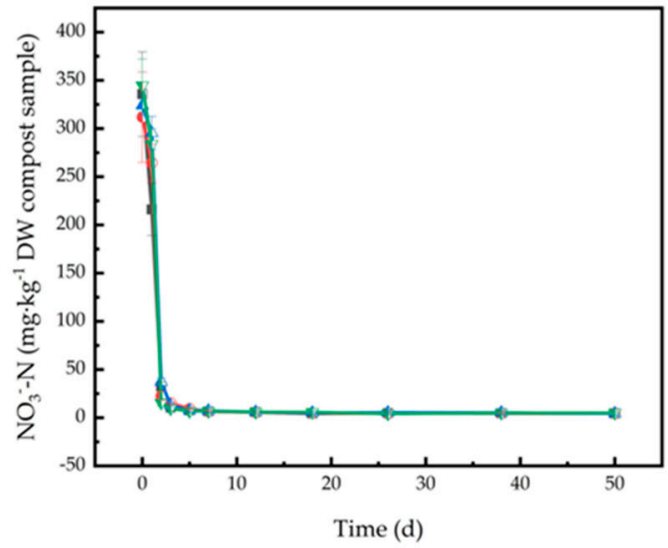

(b)

Figure 2. Changes of (a) ammonium $\left(\mathrm{NH}_{4}{ }^{+}-\mathrm{N}\right)$ and (b) nitrate $\left(\mathrm{NO}_{3}{ }^{-}-\mathrm{N}\right)$ for different treatments during agricultural waste composting. Run A: control; Run B: zeolite addition (5\%); Run C: biochar addition (5\%); Run D: zeolite (5\%) + biochar (5\%) addition. DW: dry weight.

The TOM affects and reflects the growth and reproduction of microbial communities during the composting process. The TOM of Runs A, B, C, and D on day 0 was $61.25 \%, 62.26 \%, 65.69 \%$, and $65.26 \%$, respectively. The addition of zeolite and biochar was beneficial to the growth and reproduction of microorganisms and promoted their activity. TOM declined gradually, with the contents of Runs A, B, C, and D reaching $38.61 \%, 36.22 \%, 38.63 \%$, and $38.89 \%$, respectively, on day 50 . The content of TOM in treatment B (zeolite addition) decreased sharply during the first fermentation phase and was the lowest at the maturation stage (Figure 3a). The changes of WSOC showed a trend of first increasing (days 0-7) and then decreasing (days 8-50). The microbial communities decomposed the organic materials in the compost, and the WSOC gradually decreased. The final WSOC contents for Runs A-D were 7 483.2, 7 533.8, 8 611.5, and 5793.3 mg/kg DW sample, respectively (Figure 3b).

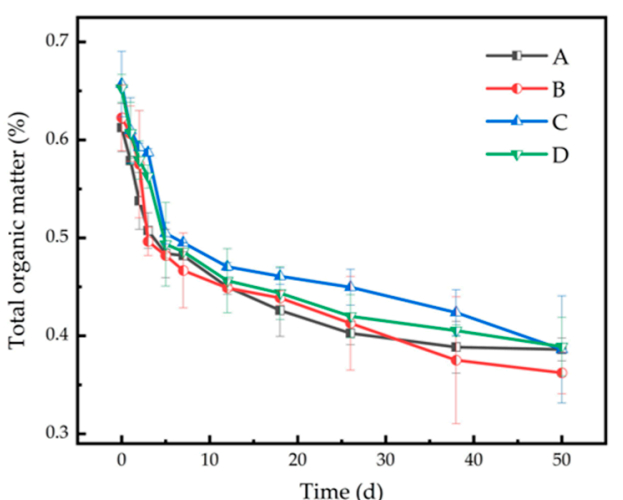

(a)

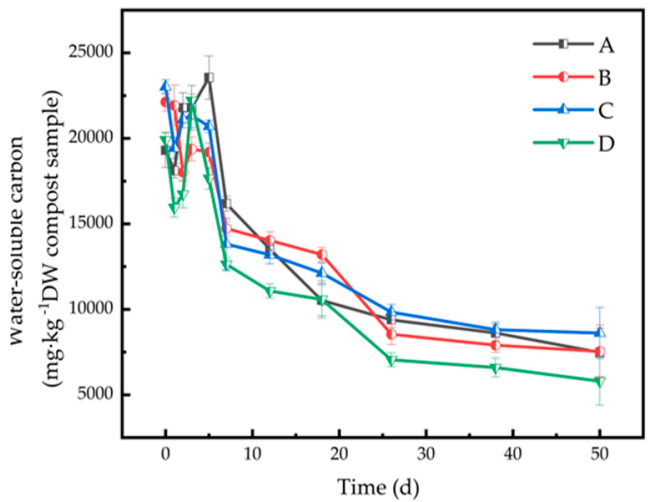

(b)

Figure 3. Changes of (a) total organic matter (TOM) and (b) water-soluble carbon (WSOC) for different treatments during agricultural waste composting. Run A: control; Run B: zeolite addition (5\%); Run C: biochar addition (5\%); Run D: zeolite (5\%) + biochar (5\%) addition. DW: dry weight.

\subsection{Bacterial Community Structure}

The phylogenetic characteristics of the bacterial community structure at the family-level are shown in Figure 4. In total, 12 dominant bacterial families, such as Nocardiopsaceae, Bacillaceae, Leuconostocaceae, Phyllobacteriaceae, Xanthomonadaceae, etc., were found in all treatments throughout the composting process, with a relative abundance of $58.55-87.01 \%$. Runs A and B had similar dominant families, while Runs $C$ and D were similar. In the initial phase, the relative 
abundance of Moraxellaceae in Runs A and B was $29.66 \%$ and $36.83 \%$, and that in Runs C and D was $5.96 \%$ and $7.56 \%$, respectively. At the end of composting, the final relative abundance of Moraxellaceae in Runs A-D was $0.07 \%, 0.03 \%, 0.04 \%$, and $0.04 \%$. Moraxellaceae are mostly parasitic bacteria, and some of the genus populations have the ability to denitrify. The less Moraxellaceae in Runs B-D indicated that adding zeolite and biochar weakened the growth of denitrifiers, and thus inhibited the denitrification activity. Nocardiopsaceae rapidly increased in the early stage and were in a relatively stable stage during the composting process. The Moraxellaceae and Cellvibrionaceae species were introduced into the composting substrate by zeolite and biochar addition, respectively, but decreased afterward. In the subsequent composting process, microbial communities in Runs B-D showed more changes than Run A. The Bacillaceae, which has the ability to inhibit harmful bacteria and immobilize molecular nitrogen, was the most active bacterial species from day 5 to day 11 in Run B.

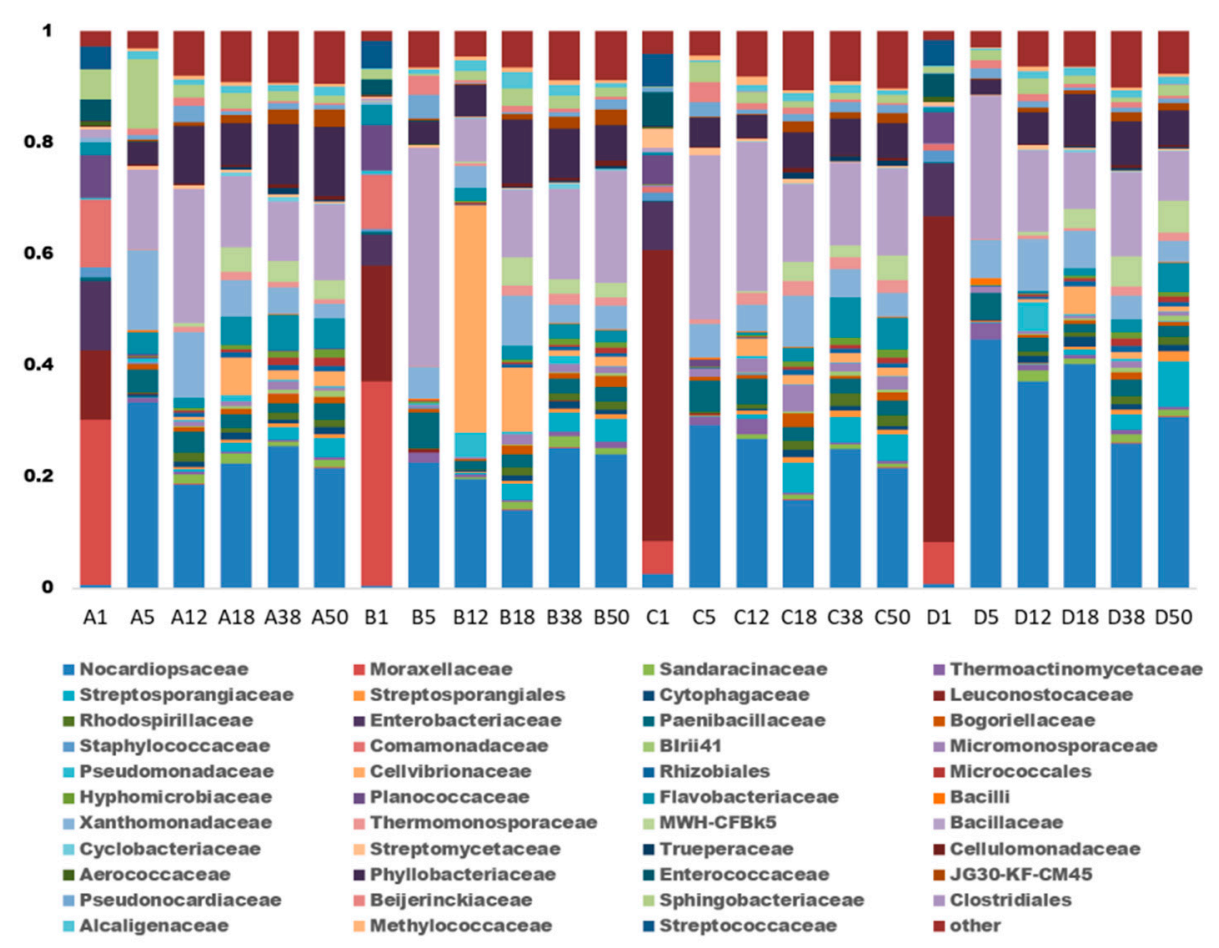

Figure 4. The relative abundance of bacterial populations for different treatments at the family-level during agricultural waste composting. Run A: control; Run B: zeolite addition (5\%); Run C: biochar addition (5\%); Run D: zeolite (5\%) + biochar (5\%) addition.

\subsection{Fungal Community Structure}

As could be seen in Figure 5, the diversity of fungi was significantly lower than that of bacteria. A total of 25 fungal species were detected, the top 12 of which accounted for $97.50-99.98 \%$ of the four treatments. Chaetomiaceae, Trichocomaceae, norank_Eurotiales, unclassified_Saccharomycetales, norank_Ascomycota, unclassified_Sordariales, Psathyrella-ceae, and Wallemiaceae were the dominant populations. The two most dominant fungal communities were Chaetomiaceae and Trichocomaceae. Chaetomiaceae began to increase on day 12 and was the dominant population until the end of the composting process. The highest abundance of Chaetomiaceae in Run A reached up to $75.28 \%$ and was subjected to $57.51 \%, 73.21 \%$, and $68.70 \%$ at a later stage. Although Chaetomiaceae in Run B peaked to $70.52 \%$ on day 18 , it was significantly lower than Run A overall, and those in Runs C and D were also lower than Run A. 


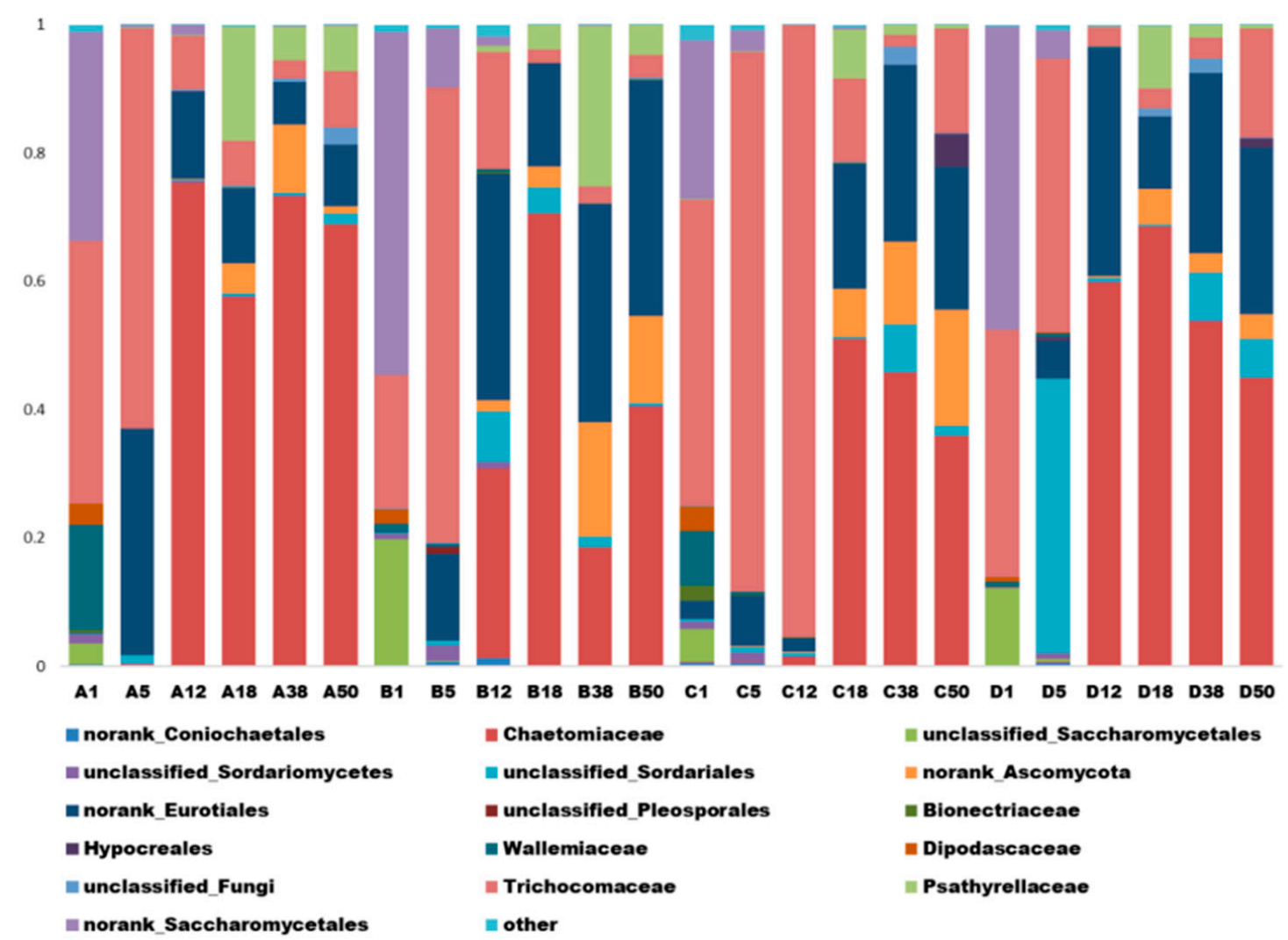

Figure 5. The relative abundance of fungal populations for different treatments at the family-level during agricultural waste composting. Run A: control; Run B: zeolite addition (5\%); Run C: biochar addition (5\%); Run D: zeolite (5\%) + biochar (5\%) addition.

Trichocomaceae are adapted to extreme environmental conditions and distributed throughout the world, mostly in soil and decaying plants and food. With the rise of temperature, microorganisms began to decompose organic compounds in large quantities. On day 5 , the abundance of Trichocomaceae reached the peak value in Runs A, B, and D, and that in Run C was $95.41 \%$ on day 12 with the disappearance of other fungi. With the end of the thermophilic stage, the abundance of Trichocomaceae gradually decreased. The final abundance of Trichocomaceae in Runs A-D was 8.78\%, 3.50\%, $16.13 \%$, and $17.00 \%$, respectively. These results suggested that biochar affected the growth and reproduction of Trichocomaceae, and the mixture of zeolite and biochar was more conducive to Trichocomaceae in the later composting process.

\subsection{Shaping Factors of Bacterial and Fungal Communities}

Redundancy analysis indicated that bacterial and fungal community structure shared different relationships with physico-chemical parameters in different treatments (Table 2). For the bacterial community, the shaping factors in Runs A-D were TOM and $\mathrm{NO}_{3}{ }^{-}-\mathrm{N}$ (Run A), $\mathrm{pH}$ (Run B), $\mathrm{pH}$ and WSOC (Run C), and pH (Run D), respectively. These factors explained 94.2\% $(F=17.90, p=0.002$ ), $73.7 \%(F=11.2, p=0.004), 93.9 \%(F=16.9, p=0.002)$, and $78.4 \%(F=14.5, p=0.002)$ of the variations in the bacterial community structure of Runs A-D. The $\mathrm{pH}$ was a significant factor in Runs B-D, indicating that the zeolite and biochar addition changed the pile $\mathrm{pH}$, thus affecting the bacterial population.

As for fungal communities, the key factors were TOM (Run A), WSOC and $\mathrm{NO}_{3}{ }^{-} \mathrm{N}$ (Run B), TOC (Run C), and TOM (Run D), respectively (Table 3). TOM was the only significant factor in Runs A, C, and $\mathrm{D}$ with an explanation of $76.4 \%(F=13.0, p=0.008), 62.4 \%(F=6.6, p=0.006)$, and $73.3 \%(F=6.3$, $p=0.006)$ of variations in fungal community composition. In addition, the shaping factors in Run $B$ 
added with zeolite were WSOC with a $65.0 \%$ explanation $(F=7.4, p=0.010)$ and $\mathrm{NO}_{3}{ }^{-}-\mathrm{N}$ with a $16.5 \%$ explanation $(F=2.7, p=0.016)$.

Table 2. Significant factors, structure explained (\%), $F$ values, and $p$ values obtained from the redundancy analysis for bacterial community composition.

\begin{tabular}{ccccc}
\hline Treatments & Significant Factor & Structure Explained/\% & $\boldsymbol{F}$ & $p$ \\
\hline \multirow{3}{*}{ Run A } & $\mathrm{TOM}$ & 82.01 & 13.9 & 0.002 \\
& $\mathrm{NO}_{3}^{-}-\mathrm{N}$ & 10.85 & 5.7 & 0.012 \\
& Cumulative explain & 92.26 & - & - \\
\hline \multirow{2}{*}{ Run B } & $\mathrm{pH}$ & 77.74 & 11.2 & 0.006 \\
& Cumulative explain & 77.74 & - & - \\
\hline \multirow{2}{*}{ Run C } & $\mathrm{pH}$ & 77.08 & 11.9 & 0.028 \\
& WSOC & 14.78 & 6.3 & 0.032 \\
& Cumulative explain & 91.86 & - & - \\
\hline \multirow{2}{*}{ Run D } & pH & 78.43 & 6.3 & 0.006 \\
& Cumulative explain & 78.43 & - & - \\
\hline
\end{tabular}

TOM: Total organic matter; $\mathrm{NO}_{3}{ }^{-}$-N: Nitrate; WSOC: water-soluble carbon.

Table 3. Significant factors, $F$ values, and $p$ values obtained from the redundancy analysis for fungal community composition.

\begin{tabular}{ccccc}
\hline Treatments & Significant Factor & Structure Explained/\% & $\boldsymbol{F}$ & $\boldsymbol{p}$ \\
\hline \multirow{2}{*}{ Run A } & $\begin{array}{c}\text { TOM } \\
\text { Cumulative } \\
\text { explain }\end{array}$ & 76.44 & 13.0 & 0.008 \\
& 76.44 & - & - \\
Run B & $\begin{array}{l}\text { WSOC } \\
\mathrm{NO}^{-}-\mathrm{N}\end{array}$ & 66.74 & 7.4 & 0.010 \\
& $\begin{array}{c}\text { Cumulative } \\
\text { explain }\end{array}$ & 14.70 & 2.7 & 0.016 \\
\hline \multirow{2}{*}{ Run C } & $\begin{array}{c}\text { TOM } \\
\text { Cumulative } \\
\text { explain }\end{array}$ & 61.44 & - & - \\
\hline \multirow{2}{*}{ Run D } & $\begin{array}{c}\text { TOM } \\
\text { Cumulative } \\
\text { explain }\end{array}$ & 62.44 & - & 0.006 \\
& 62.39 & 6.3 & 0.006 \\
\hline
\end{tabular}

TOM: Total organic matter; $\mathrm{NO}_{3}{ }^{-}-\mathrm{N}$ : Nitrate; WSOC: water-soluble carbon.

\section{Discussion}

Pile temperature maintained for more than five days could effectively kill pathogenic microbes and ensure the compost harmlessness [27]. The pile temperature gradually decreased afterward as the easily degradable organic matter was consumed by microbial communities [22,28]. The bulking effect of zeolite might be beneficial to microbial activities and at the same time to enhance the heat loss to the environment $[10,29]$. The $\mathrm{pH}$ decreased afterward with the ammonia volatilization and the nitrification increase, as well as the production of organic acids by the biodegradation of organics [30]. Previous studies have shown that combination zeolite and biochar stimulated nitrogen retention during composting [21,31]. Biochar and zeolite have sieving and selective adsorption properties for $\mathrm{H}_{2} \mathrm{O}$, $\mathrm{NH}_{3}, \mathrm{CO}_{2}$, etc. As a mineral with an open network structure, zeolite controlled various cations in and out through cation exchange reaction and adsorption [32]. Zeolite can reduce the $\mathrm{NH}_{3}$ volatilization loss by up to $44 \%$ during the composting of poultry manure [33]. Biochar was widely used as an amendment for improving composting conditions and the quality of compost products [34]. During the thermophilic and cooling phases, the $\mathrm{NH}_{3}$ volatilization was reduced significantly due to the 
addition of biochar, and the pile temperature and $\mathrm{NO}_{3}{ }^{-}-\mathrm{N}$ were increased throughout the composting process [17]. Biochar and zeolite addition can provide better aeration conditions and decrease the space of water-filled pore, which might be a potential mechanism for the reduction of greenhouse gas emissions. Additionally, changes in water content by biochar and zeolite affected the transportation or leaching of nutrients, such as nitrogen compounds [35].

Bacillaceae was dominant during the thermophilic stage and was often reported during composting [36-38]. A previous study indicated that after biochar addition, the abundances of Nitriliruptoraceae and Bacillaceae in the poultry manure increased, while those of Alcaligenaceae, Rhodispirillaceae, and Xanthomonadaceae in cow manure increased [39]. In the process of composting straw and pig manure, Firmicutes, Actinobacteria, and Proteobacteria were the dominant ones, and the relative abundance of Actinobacteria increased in a statistically significant way, especially its genus of Saccharomonospora [40]. The highest abundance of mesophilic bacteria, endospores bacteria, and actinomycetes were obtained after seven days of municipal solid waste composting with biochar addition [1]. Mesophilic fungi as well as thermophilic fungi were the least frequent in fresh initial samples [1]. The addition of biochar to compost with sewage sludge decreased the abundance of indicative microorganisms E. coli and Salmonella ssp. and increased the total number of bacteria and fungi [41]. The physico-chemical characteristics of biochar and zeolite may explain the observed changes in the bacterial and fungal communities. Biochar and zeolite reduced the bulk density of composting piles and changed the natural ventilation of compost. The biochar may also affect the microbial colonization as the pores on the surface of zeolite and biochar are favorable for many spores, bacteria, and other microbial communities [42]. Previous research has shown that the application of different concentrations of wheat straw biochar has significantly different fungal communities [43]. The influence of the increasing addition of biochar (produced from wood chips) on the increasing abundance of the thermophilic bacterial community was also observed [1].

Biochar promoted the carbon input into the compost substrate and therefore stimulated the growth and reproduction of the bacterial community. The increase of bacteria in the early stage was due to the easily bioavailable organic matter which stimulated the growth of bacteria and the synthesis of enzymes. With the drop in pile temperature and consumption of simple organic matter, the number of microbial communities continued to decline. Zeolite and biochar addition changed the physic-chemical properties during composting in many ways, inducing variations in microbial communities and their function. Bacterial and fungal community abundance increased during the first fermentation phase was likely due to the higher content of degradable organic compounds in the composting mixture which might stimulate their growth and enzyme synthesis. By adsorption or changing the condition of the water during composting, zeolite and biochar will change the utilization of nutrients and others affecting microbial growth and activity, such as carbon substrates, electron acceptors, and toxins. A previous study showed no inhibitory effects on microbial activity after application of zeolite [44]. The addition of biochar and zeolite increased the input of carbon source and stimulated the growth and reproduction of microbial communities. Biochar addition increased the richness of bacterial species associated with carbohydrate metabolism, amino acid metabolism, and energy metabolism during pig manure composting with rice straw with a biochar addition [40]. Biochar addition increased the respiration and decomposition rates, proving the promotion of microbial activity $[1,17,45]$. Small molecular substances were filled into the pores of biochar during and after composting [46]. Moreover, it provided a nitrogen source and reduced free $\mathrm{NH}_{3}$ toxicity to microorganisms as a hotbed for culturing microbial communities [47].

Plenty of studies have shown that sample properties (e.g., substrate utilizable, pile temperature, and $\mathrm{C} / \mathrm{N}$ ratio) were changed by biochar/zeolite addition during agricultural waste composting. Confirming which physico-chemical parameters significantly influenced the microbial communities is propitious to better explain changes during the waste composting system with different addition strategies [2,48]. Biochar and zeolite are most likely to indirectly affect the bacterial and fungal communities by the increased pile temperature, enhanced substrate utilization, and other changed 
factors. Dissolved organic carbon (DOC) was a key factor that influenced microbial community structure and metabolic type during agricultural waste composting [30,49], which was largely because of the different physiological adaptability of microbial species to different nutritional conditions [49]. The fermenting metabolism might occur in an environment with a higher level of WSOC, and respiratory metabolism seemed to occur when WSC was scarce [49]. DOC and TN were the key determining factors of the bacterial community composition when green waste and a manure mix were composted with biochar addition [50]. According to network analysis, DOC had strong positive correlations with a few bacterial species, such as Comamonas, Leucobacter, and Acidimicrobiales, while TN had negative correlations with other taxa, such as Microbacteriaceae and Aeromicrobium [50]. The variation analysis of the bacterial community showed that the activity of bacteria in the thermophilic period was controlled by WSC content and pile temperature, while the electrical conductivity and total amount of Kjeldahl nitrogen also affected the maturity of compost [51]. A previous study also indicated that the addition of biochar had a great effect on $\mathrm{TN}$, and TN had the greatest effect on the bacterial community structure during the process of rice straw and pig manure composting [40].

Several researchers have emphasized the importance and effect of the $\mathrm{C} / \mathrm{N}$ ratio on the microbial community structure and activity during composting [52]. Samples of compost with a lower $\mathrm{C} / \mathrm{N}$ ratio were usually responsible for higher bacterial/fungal ratio during agricultural waste composting [52]. Biochar and zeolite addition stimulated bacterial community activities over a relatively long time, and less organic matter available is left for fungal growth when the pile temperature drops to the allowable levels [52]. Most biochar is alkaline and increases $\mathrm{pH}$ in different experiments. Biochar can promote direct interspecies electron transfer similar to granular-activated carbon [53]. The amount of water-filled pores influences oxygen concentrations in the composting process, thus the water-filled pore space largely determines the extent and relative ratio of different nitrogen transformation processes [54]. A medium for the transport of dissolved nutrients needed for the metabolic and physiological activities of microbial communities is provided by moisture in composting materials. Our previous research suggested that the fungal community might be more sensitive to moisture regulation than the bacterial counterparts [55]. Further studies are needed to determine the ecology and functions of microorganisms related to nitrogen transformation when biochar/zeolite is added during the agricultural waste composting process [56,57].

\section{Conclusions}

The study was conducted to determine the effects of zeolite and biochar addition on the microbial community during composting. The results indicated that the addition of biochar and zeolite significantly changed the structure of the microbial community. The additions of biochar, zeolite, and a combination of them have a positive effect on improving the organic matter degradation as well as increasing the content of effective nutrients during agricultural waste composting. Physico-chemical parameters, e.g., $\mathrm{pH}$, total organic matter, and nitrate, were the most important ones affecting the bacterial and fungal population changes during the composting process with zeolite and biochar addition.

Author Contributions: Conceptualization, X.W. and L.R.; methodology, X.W. and L.R.; software, L.R. and L.Z.; validation, X.W., L.R., and L.L.; formal analysis, X.W., L.R., and H.H.; investigation, L.R. and L.L.; resources, L.R., L.L., and J.Z.; data curation, X.W. and L.R.; writing-original draft preparation, X.W. and H.H.; writing-review and editing, L.L. and H.H.; visualization, L.L. and H.H.; supervision, L.L. and J.Z.; project administration, L.L. and H.H.; funding acquisition, L.L. and J.Z. All authors have read and agreed to the published version of the manuscript.

Funding: This research was funded by the Natural Science Foundation of Hunan Province (2020JJ5259) and the Outstanding Youth Fund project of the Hunan Education Department (18B094).

Acknowledgments: The authors would like to thank the anonymous reviewers for their valuable comments and suggestions on the previous versions of this paper.

Conflicts of Interest: The authors declare no conflict of interest. 


\section{References}

1. Malinowski, M.; Wolny-Koładka, K.; Vaverková, M.D. Effect of biochar addition on the OFMSW composting process under real conditions. Waste Manag. 2019, 84, 364-372. [CrossRef]

2. Ren, L.; Cai, C.; Zhang, J.; Yang, Y.; Wu, G.; Luo, L.; Huang, H.; Zhou, Y.; Qin, P.; Yu, M. Key environmental factors to variation of ammonia-oxidizing archaea community and potential ammonia oxidation rate during agricultural waste composting. Bioresour. Technol. 2018, 270, 278-285. [CrossRef] [PubMed]

3. Zeng, G.; Cheng, M.; Huang, D.; Lai, C.; Xu, P.; Wei, Z.; Li, N.; Zhang, C.; He, X.; He, Y. Study of the degradation of methylene blue by semi-solid-state fermentation of agricultural residues with Phanerochaete chrysosporium and reutilization of fermented residues. Waste Manag. 2015, 38, 424-430. [CrossRef] [PubMed]

4. Chen, R.; Wang, Y.; Wang, W.; Wei, S.; Jing, Z.; Lin, X. $\mathrm{N}_{2} \mathrm{O}$ emissions and nitrogen transformation during windrow composting of dairy manure. J. Environ. Manag. 2015, 160, 121-127. [CrossRef] [PubMed]

5. Guillermo, P.; Raúl, M.; Eduardo, A.; Agustín, D.P. Gaseous emissions from management of solid waste: A systematic review. Glob. Chang. Biol. 2015, 21, 1313-1327.

6. Bernal, M.P.; Alburquerque, J.A.; Moral, R. Composting of animal manures and chemical criteria for compost maturity assessment. A review. Bioresour. Technol. 2009, 100, 5444-5453. [CrossRef]

7. Sanchez-Garcia, M.; Alburquerque, J.A.; Sanchez-Monedero, M.A.; Roig, A.; Cayuela, M.L. Biochar accelerates organic matter degradation and enhances $\mathrm{N}$ mineralisation during composting of poultry manure without a relevant impact on gas emissions. Bioresour. Technol. 2015, 192, 272-279. [CrossRef]

8. Zhang, L.; Dong, H.; Zhang, J.; Chen, Y.; Zeng, G.; Yuan, Y.; Cao, W.; Fang, W.; Hou, K.; Wang, B.; et al. Influence of FeONPs amendment on nitrogen conservation and microbial community succession during composting of agricultural waste: Relative contributions of ammonia-oxidizing bacteria and archaea to nitrogen conservation. Bioresour. Technol. 2019, 287, 121463. [CrossRef]

9. Fang, M.; Wong, J.W.C.; Ma, K.K.; Wong, M.H. Co-composting of sewage sludge and coal fly ash: Nutrient transformations. Bioresour. Technol. 1999, 67, 19-24. [CrossRef]

10. Villasenor, J.; Rodriguez, L.; Fernandez, F.J. Composting domestic sewage sludge with natural zeolites in a rotary drum reactor. Bioresour. Technol. 2011, 102, 1447-1454. [CrossRef]

11. Wong, J.W.; Selvam, A. Speciation of heavy metals during co-composting of sewage sludge with lime. Chemosphere 2006, 63, 980-986. [CrossRef] [PubMed]

12. Lim, S.-S.; Park, H.-J.; Hao, X.; Lee, S.-I.; Jeon, B.-J.; Kwak, J.-H.; Choi, W.-J. Nitrogen, carbon, and dry matter losses during composting of livestock manure with two bulking agents as affected by co-amendments of phosphogypsum and zeolite. Ecol. Eng. 2017, 102, 280-290. [CrossRef]

13. Mierzwa-Hersztek, M.; Wolny-Koładka, K.; Gondek, K.; Gałązka, A.; Gawryjołek, K. Effect of coapplication of biochar and nutrients on microbiocenotic composition, dehydrogenase activity index and chemical properties of sandy soil. Waste Biomass Valoriz. 2020, 11, 3911-3923. [CrossRef]

14. Liu, N.; Liao, P.; Zhang, J.; Zhou, Y.; Luo, L.; Huang, H.; Zhang, L. Characteristics of denitrification genes and relevant enzyme activities in heavy-metal polluted soils remediated by biochar and compost. Sci. Total Environ. 2020, 739, 139987. [CrossRef]

15. Tang, J.; Zhang, L.; Zhang, J.; Ren, L.; Zhou, Y.; Zheng, Y.; Luo, L.; Yang, Y.; Huang, H.; Chen, A. Physicochemical features, metal availability and enzyme activity in heavy metal-polluted soil remediated by biochar and compost. Sci. Total Environ. 2020, 701, 134751. [CrossRef]

16. Jindo, K.; Suto, K.; Matsumoto, K.; Garcia, C.; Sonoki, T.; Sanchez-Monedero, M.A. Chemical and biochemical characterisation of biochar-blended composts prepared from poultry manure. Bioresour. Technol. 2012, 110, 396-404. [CrossRef]

17. Malińska, K.; Zabochnicka-Świątek, M.; Dach, J. Effects of biochar amendment on ammonia emission during composting of sewage sludge. Ecol. Eng. 2014, 71, 474-478. [CrossRef]

18. Maulini-Duran, C.; Artola, A.; Font, X.; Sanchez, A. Gaseous emissions in municipal wastes composting: Effect of the bulking agent. Bioresour. Technol. 2014, 172, 260-268. [CrossRef]

19. Chan, M.T.; Selvam, A.; Wong, J.W. Reducing nitrogen loss and salinity during 'struvite' food waste composting by zeolite amendment. Bioresour. Technol. 2016, 200, 838-844. [CrossRef]

20. Awasthi, M.K.; Wang, Q.; Huang, H.; Ren, X.; Lahori, A.H.; Mahar, A.; Ali, A.; Shen, F.; Li, R.; Zhang, Z. Influence of zeolite and lime as additives on greenhouse gas emissions and maturity evolution during sewage sludge composting. Bioresour. Technol. 2016, 216, 172-181. [CrossRef] 
21. Awasthi, M.K.; Wang, Q.; Ren, X.; Zhao, J.; Huang, H.; Awasthi, S.K.; Lahori, A.H.; Li, R.; Zhou, L.; Zhang, Z. Role of biochar amendment in mitigation of nitrogen loss and greenhouse gas emission during sewage sludge composting. Bioresour. Technol. 2016, 219, 270-280. [CrossRef] [PubMed]

22. Czekala, W.; Malinska, K.; Caceres, R.; Janczak, D.; Dach, J.; Lewicki, A. Co-composting of poultry manure mixtures amended with biochar-The effect of biochar on temperature and $\mathrm{C}-\mathrm{CO}_{2}$ emission. Bioresour. Technol. 2016, 200, 921-927. [CrossRef]

23. Zhang, J.; Luo, L.; Gao, J.; Peng, Q.; Huang, H.; Chen, A.; Lu, L.; Yan, B.; Wong, J.W.C. Ammonia-oxidizing bacterial communities and shaping factors with different Phanerochaete chrysosporium inoculation regimes during agricultural waste composting. RSC Adv. 2016, 6, 61473-61481. [CrossRef]

24. O'Reilly, J.; Lee, C.; Chinalia, F.; Collins, G.; Mahony, T.; O’Flaherty, V. Microbial community dynamics associated with biomass granulation in low-temperature (15 degrees $\mathrm{C}$ ) anaerobic wastewater treatment bioreactors. Bioresour. Technol. 2010, 101, 6336-6344. [CrossRef] [PubMed]

25. Yao, Q.; Liu, J.; Yu, Z.; Li, Y.; Jin, J.; Liu, X.; Wang, G. Three years of biochar amendment alters soil physiochemical properties and fungal community composition in a black soil of northeast China. Soil Biol. Biochem. 2017, 110, 56-67. [CrossRef]

26. Lepš, J.; Šmilauer, P. Multivariate Analysis of Ecological Data Using CANOCO; Cambridge University Press: Cambridge, UK, 2003; pp. 43-75.

27. Wang, Q.; Wang, Z.; Awasthi, M.K.; Jiang, Y.; Li, R.; Ren, X.; Zhao, J.; Shen, F.; Wang, M.; Zhang, Z. Evaluation of medical stone amendment for the reduction of nitrogen loss and bioavailability of heavy metals during pig manure composting. Bioresour. Technol. 2016, 220, 297-304. [CrossRef] [PubMed]

28. Wang, C.; Lu, H.; Dong, D.; Deng, H.; Strong, P.J.; Wang, H.; Wu, W. Insight into the effects of biochar on manure composting: Evidence supporting the relationship between $\mathrm{N}_{2} \mathrm{O}$ emission and denitrifying community. Environ. Sci. Technol. 2013, 47, 7341-7349. [CrossRef]

29. Zhang, J.; Sui, Q.; Li, K.; Chen, M.; Tong, J.; Qi, L.; Wei, Y. Influence of natural zeolite and nitrification inhibitor on organics degradation and nitrogen transformation during sludge composting. Environ. Sci. Pollut. Res. 2017, 24, 9122. [CrossRef]

30. Zhang, J.; Zeng, G.; Chen, Y.; Yu, M.; Yu, Z.; Li, H.; Yu, Y.; Huang, H. Effects of physico-chemical parameters on the bacterial and fungal communities during agricultural waste composting. Bioresour. Technol. 2011, 102, 2950-2956. [CrossRef]

31. Awasthi, M.K.; Wang, M.; Pandey, A.; Chen, H.; Awasthi, S.K.; Wang, Q.; Ren, X.; Lahori, A.H.; Li, D.S.; Li, R.; et al. Heterogeneity of zeolite combined with biochar properties as a function of sewage sludge composting and production of nutrient-rich compost. Waste Manag. 2017, 68, 760-773. [CrossRef]

32. Venglovsky, J.; Sasakova, N.; Vargova, M.; Pacajova, Z.; Placha, I.; Petrovsky, M.; Harichova, D. Evolution of temperature and chemical parameters during composting of the pig slurry solid fraction amended with natural zeolite. Bioresour. Technol. 2005, 96, 181-189. [CrossRef]

33. Kithome, M.; Paul, J.; Bomke, A. Reducing nitrogen losses during simulated composting of poultry manure using adsorbents or chemical amendments. J. Environ. Qual. 1999, 28, 194-201. [CrossRef]

34. Steiner, C.; Das, K.C.; Melear, N.; Lakly, D. Reducing nitrogen loss during poultry litter composting using biochar. J. Environ. Qual. 2010, 39, 1236-1242. [CrossRef] [PubMed]

35. Clough, T.; Condron, L.; Kammann, C.; Müller, C. A review of biochar and soil nitrogen dynamics. Agronomy 2013, 3, 275-293. [CrossRef]

36. Partanen, P.; Hultman, J.; Paulin, L.; Auvinen, P.; Romantschuk, M. Bacterial diversity at different stages of the composting process. BMC Microbiol. 2010, 10, 94. [CrossRef]

37. Karadag, D.; Özkaya, B.; Ölmez, E.; Nissilä, M.E.; Çakmakçı, M.; Yıldız, Ş.; Puhakka, J.A. Profiling of bacterial community in a full-scale aerobic composting plant. Int. Biodeterior. Biodegrad. 2013, 77, 85-90. [CrossRef]

38. Tashiro, Y.; Tabata, H.; Itahara, A.; Shimizu, N.; Tashiro, K.; Sakai, K. Unique hyper-thermal composting process in Kagoshima City forms distinct bacterial community structures. J. Biosci. Bioeng. 2016, 122, 606-612. [CrossRef]

39. Qiu, X.; Zhou, G.; Zhang, J.; Wang, W. Microbial community responses to biochar addition when a green waste and manure mix are composted: A molecular ecological network analysis. Bioresour. Technol. 2019, 273, 666-671. [CrossRef] 
40. Zhou, G.; Xu, X.; Qiu, X.; Zhang, J. Biochar influences the succession of microbial communities and the metabolic functions during rice straw composting with pig manure. Bioresour. Technol. 2019, 272, 10-18. [CrossRef]

41. Kopeć, M.; Baran, A.; Mierzwa-Hersztek, M.; Gondek, K.; Chmiel, J.M. Effect of the addition of biochar and coffee grounds on the biological properties and ecotoxicity of composts. Waste Biomass Valoriz. 2018, 9 , 1389-1398.

42. Hien Quoc, N.; Larsson, E.G.; Marzetta, T.L. Energy and spectral efficiency of very large multiuser MIMO systems. IEEE Trans. Commun. 2013, 61, 1436-1449. [CrossRef]

43. Duan, Y.; Awasthi, S.K.; Liu, T.; Chen, H.; Zhang, Z.; Wang, Q.; Ren, X.; Tu, Z.; Awasthi, M.K.; Taherzadeh, M.J. Dynamics of fungal diversity and interactions with environmental elements in response to wheat straw biochar amended poultry manure composting. Bioresour. Technol. 2019, 274, 410-417. [CrossRef] [PubMed]

44. Madrini, B.; Shibusawa, S.; Kojima, Y.; Hosaka, S. Effect of natural zeolite (clinoptilolite) on ammonia emissions of leftover food-rice hulls composting at the initial stage of the thermophilic process. J. Agric. Meteorol. 2016, 72, 12-19. [CrossRef]

45. Khan, N.; Clark, I.; Sanchez-Monedero, M.A.; Shea, S.; Meier, S.; Bolan, N. Maturity indices in co-composting of chicken manure and sawdust with biochar. Bioresour. Technol. 2014, 168, 245-251. [CrossRef] [PubMed]

46. Agyarko-Mintah, E.; Cowie, A.; Singh, B.P.; Joseph, S.; Van Zwieten, L.; Cowie, A.; Harden, S.; Smillie, R. Biochar increases nitrogen retention and lowers greenhouse gas emissions when added to composting poultry litter. Waste Manag. 2017, 61, 138-149. [CrossRef] [PubMed]

47. Sun, D.; Lan, Y.; Xu, E.G.; Meng, J.; Chen, W. Biochar as a novel niche for culturing microbial communities in composting. Waste Manag. 2016, 54, 93-100. [CrossRef]

48. Zeng, G.; Zhang, J.; Chen, Y.; Yu, Z.; Yu, M.; Li, H.; Liu, Z.; Chen, M.; Lu, L.; Hu, C. Relative contributions of archaea and bacteria to microbial ammonia oxidation differ under different conditions during agricultural waste composting. Bioresour. Technol. 2011, 102, 9026-9032. [CrossRef]

49. Zhang, J.; Zeng, G.; Chen, Y.; Yu, M.; Huang, H.; Fan, C.; Zhu, Y.; Li, H.; Liu, Z.; Chen, M.; et al. Impact of Phanerochaete chrysosporium inoculation on indigenous bacterial communities during agricultural waste composting. Appl. Microbiol. Biotechnol. 2013, 97, 3159-3169. [CrossRef]

50. Ishii, K.; Takii, S. Comparison of microbial communities in four different composting processes as evaluated by denaturing gradient gel electrophoresis analysis. J. Appl. Microbiol. 2003, 95, 109-119. [CrossRef]

51. Mao, H.; Lv, Z.; Sun, H.; Li, R.; Zhai, B.; Wang, Z.; Awasthi, M.K.; Wang, Q.; Zhou, L. Improvement of biochar and bacterial powder addition on gaseous emission and bacterial community in pig manure compost. Bioresour. Technol. 2018, 258, 195-202. [CrossRef]

52. Eiland, F.; Klamer, M.; Lind, A.M.; Leth, M.; Baath, E. Influence of initial C/N ratio on chemical and microbial composition during long term composting of straw. Microb. Ecol. 2001, 41, 272-280. [CrossRef] [PubMed]

53. Chen, S.; Rotaru, A.E.; Shrestha, P.M.; Malvankar, N.S.; Liu, F.; Fan, W.; Nevin, K.P.; Lovley, D.R. Promoting interspecies electron transfer with biochar. Sci. Rep. 2014, 4, 5019. [CrossRef] [PubMed]

54. Braker, G.; Conrad, R. Diversity, structure, and size of $\mathrm{N}_{2} \mathrm{O}$-producing microbial communities in soils-what matters for their functioning? Adv. Appl. Microbiol. 2011, 75, 33-70. [PubMed]

55. Zhang, J.; Zeng, G.; Chen, Y.; Liang, J.; Zhang, C.; Huang, B.; Sun, W.; Chen, M.; Yu, M.; Huang, H.; et al. Phanerochaete chrysosporium inoculation shapes the indigenous fungal communities during agricultural waste composting. Biodegradation 2014, 25, 669-680. [CrossRef]

56. Tang, J.; Zhang, J.; Ren, L.; Zhou, Y.; Gao, J.; Luo, L.; Yang, Y.; Peng, Q.; Huang, H.; Chen, A. Diagnosis of soil contamination using microbiological indices: A review on heavy metal pollution. J. Environ. Manag. 2019, 242, 121-130. [CrossRef]

57. Wu, X.; Ren, L.; Zhang, J.; Peng, H. Effects of zeolite and Biochar addition on ammonia-oxidizing bacteria and ammonia-oxidizing Archaea communities during agricultural waste composting. Sustainability 2020, 12, 6336. [CrossRef]

(C) 2020 by the authors. Licensee MDPI, Basel, Switzerland. This article is an open access article distributed under the terms and conditions of the Creative Commons Attribution (CC BY) license (http://creativecommons.org/licenses/by/4.0/). 